\title{
Sværtning af generaler, dronninger og fine damer i Det Kongelige Biblioteks samlinger
}

En historie om hvordan svartning af blyhvidt, brugt til at skabe hojlys i aldre billeder, har sat fokus på opbevaringsforholdene.

afkonservator Birgit Vinther Hansen, Det Kongelige Bibliotek

$\mathrm{E}$

gentlig begyndte hele historien med at Statens Museum for Kunst (SMK), for et par år siden, opdagede, at de hvide højlys på nogle 500 år gamle tyske tegninger i Kobberstiksamlingen, pludseligt og meget uventet, havde skiftet farve fra hvid til sort i løbet af bare 10 år. På Det Kongelige Bibliotek havde vi på det tidspunkt kun kendskab til et enkelt værk, som på samme måde var blevet sværtet. Det var et fotografi af general Claude du Plat, der var dukket op i forbindelse med kuratering af udstillingen "Krigens Spor" i 2014 (fig. 1). Redaktøren af krigsudstillingen havde undret sig over, at generalen i stedet for en hvid skjorte tilsyneladende bar 'sørgebind' i form af en sort skjorte. Dette er et godt eksempel på, hvordan den utilsigtede mørkning af den hvide retouche, påført for at forstærke fotografiets højlys, endte med at blive meningsforstyrrende.

\section{Sværtning af blyhvidt}

Den hvide farve på SMK's tegninger og retouchen på fotografiet består af blyhvidt (basisk blykarbonat), der har været den almindeligt anvendte hvide farve til kunstværker fra oldtiden og frem til det 20. århundrede. Farven har været populær, fordi den har en fin varm tone, som ikke let har kunnet frembringes med

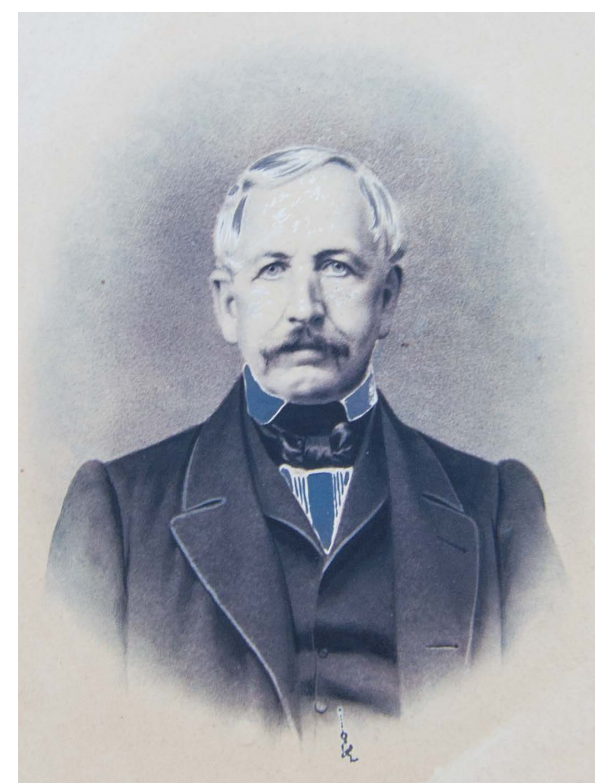

Fig. 1: Portrat af general Claude du Plat, 1809-1864 (inv. nr. 1948-384/2).

andre hvide pigmenter. Men da farven, på grund af blyindholdet, er giftig, blev den forbudt og erstattet af andre køligere hvide farver som zinkhvid og titanhvid.

Sværtning af blyhvidt er en velkendt udfordring inden for bevaring af farvelag i malerier og i illuminerede håndskrifter, idet man naturligt nok ønsker den oprindelige hvide farve bevaret. Skaden 


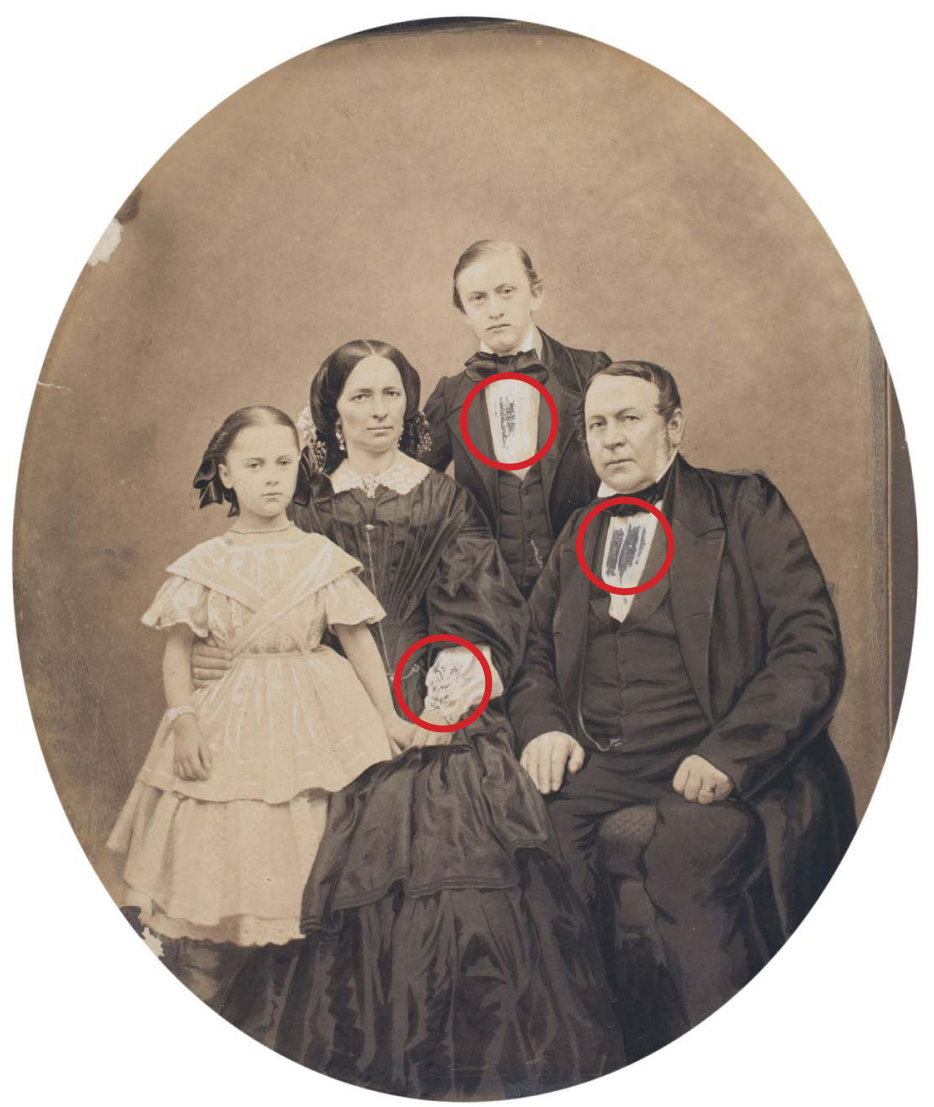

Fig. 2: Portret på saltpapir (Fot. Hist. Bl. $\left.4^{\circ} 266\right)$.

forårsages af svovlbrinte tilstede i luften, som også er det der gør sølvtøj sort. Den hvide blykarbonatholdige farve reagerer med svovlet, og bliver dermed mørkt. Svovlbrinte kommer fra nedbrydning af organisk materiale, vulkansk aktivitet eller fra biologiske fordøjelsesprocesser, men den konkrete kilde til svovlbrinteforureningen på SMK og Det Kongelige Bibliotek kunne ikke umiddelbart identificeres.

\section{En sort fremtid?}

Den alarmerende opdagelse på SMK og det, at også det Kongelige Biblioteks samlinger kunne være udsat for en ny forureningskilde, førte til det fælles forskningsprojekt En sort fremtid? En undersøgelse af mekanismer for eftermørkning af blyhvidtholdige farver på grafiske verker finansieret af Kulturministeriets Forskningspulje. ${ }^{1}$

\section{Værker med blyhvidt i Det Kongelige Biblioteks samlinger}

Projektet gav anledning til at gennemføre en større stikprøveundersøgelse i bibliotekets samlinger for at kortlægge omfanget af værker med blyhvidt, og i hvor høj grad de er ramt af sværtning. Faglitteraturen beskriver eksempler på sværtning af 
Fig. 3: Portret af Ida Augusta AlmaforteHardenberg-Reventlow (1799-1867) formentligt optaget påsaltpapir i 1856 (inv. 1949-128).

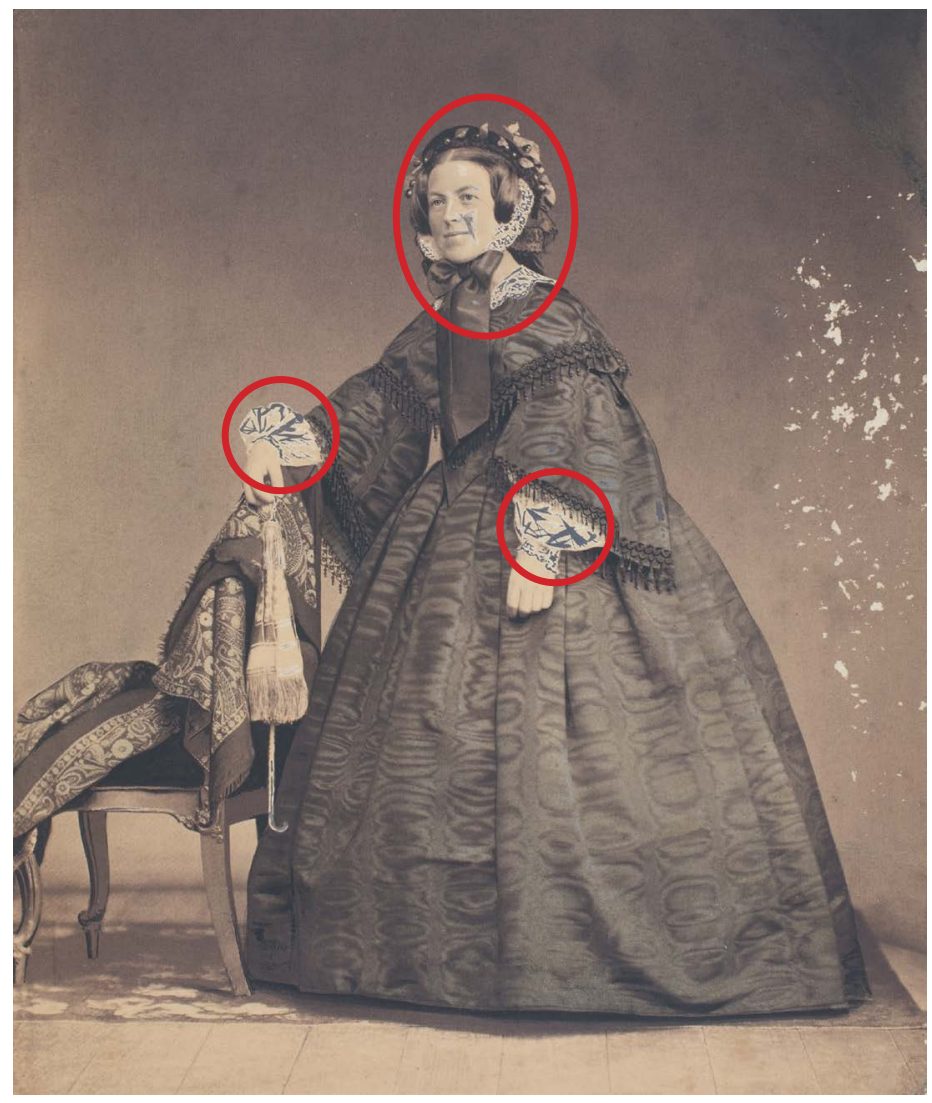

grafiske værker med blyhvidt i illuminerede håndskrifter, akvareller, gouacher og tegninger. Det Kongelige Bibliotek har således mange bog- og billedsamlinger, der teoretisk set kunne indeholde værker bemalet med blyhvidt.

Stikprøveundersøgelsen viste, at omfanget af værker med sværtet blyhvidt er begrænset til billedsamlingerne og en samling af persiske miniaturer, som har det til fælles, at de er emballeret enkeltvis og ikke er indbundne. Langt de fleste sværtede værker er fra bibliotekets portrætsamling, der indeholder både grafiske og fotografiske værker. Her fandt vi især eksempler på skaden blandt saltpapirfotografier og litografier fra perioden 1840-1870, som har været retoucheret med blyhvidt. Saltpapirbilleder er en af de allertidligste fotografiske teknikker anvendt fra 1830 'rne til ca. $1860 .{ }^{2} \mathrm{De}$ har ikke så høj kontrast og er derfor ofte retoucherede for at fremhæve detaljer. Biblioteket har en del portrætter på saltpapir fra den tid, og i de tilfælde, hvor der er brugt hvid retouche, er der som oftest anvendt blyhvidt. Ligeledes har man anvendt en markering af højlys med blyhvidt på litografier. Fundet af retoucheringer med blyhvidt på litografier og på nogle 


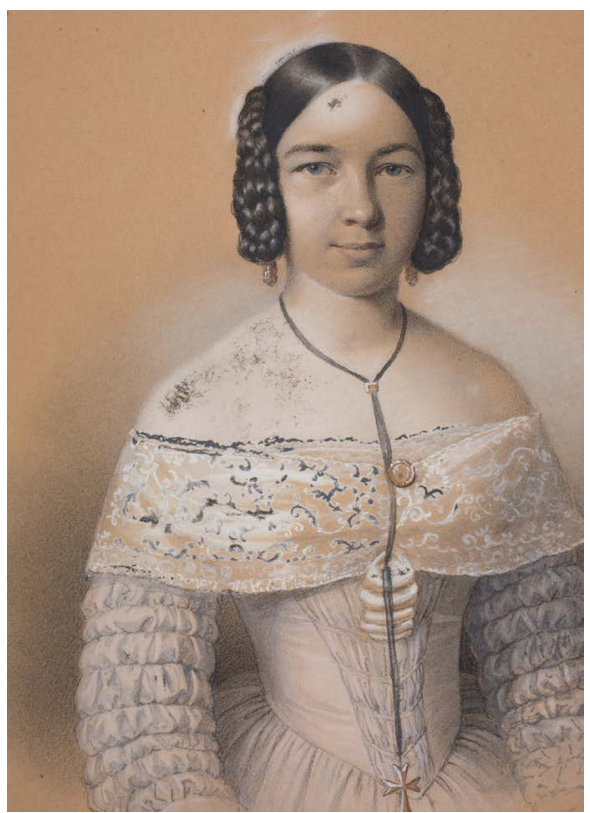

Fig. 4: Litografi af Emilie Mariane Forchhammer (inv. 1976-233/2).

af de tidligst producerede fotografier er særligt interessant, da det ikke tidligere er beskrevet i faglitteraturen.

Billederne i fig. 2-6 viser hvordan retoucherede portrætter på saltpapir og litografier er blevet påvirket af sværtningen af blyhvidt. De røde cirkler på portrætterne i fig. 2-3 indikerer områder retoucheret med blyhvidt, der er mørknet.

På det litografiske portræt af Emilie Marianne Forchhammer (fig. 4), ses at retouchen på hendes pande, skulder og kjole er mørknet. På de fleste portrætter giver sværtningen, som her, anledning til et æstetisk tab ligesom den kan være meningsforstyrrende. Et andet eksempel ses på billedet af Dronning Louise (fig. 5 og udsnit i fig. 6), der på trods af at det er en skade, viser en kjole

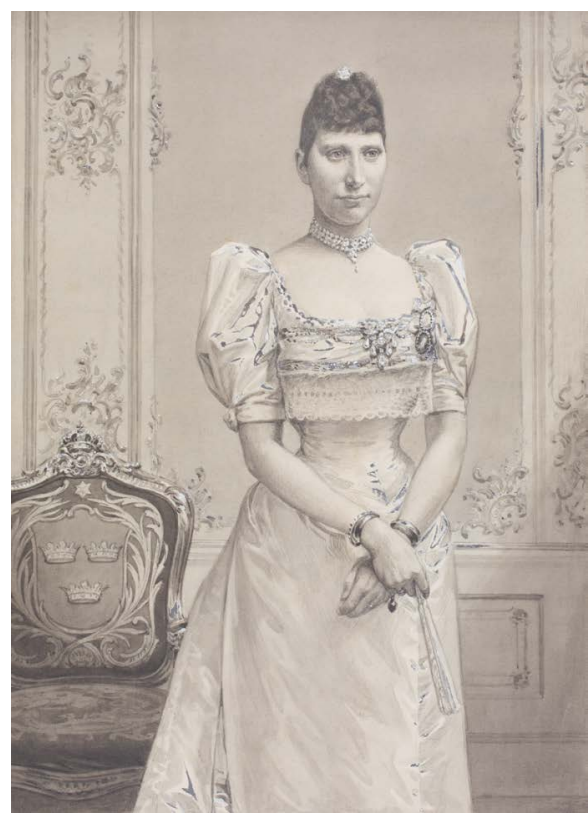

Fig. 5 (ovenfor) og 6 (modstaiende side): Litografi af Dronning Louise (1851-1926), fra hendes tid i Sverige for hun i 1869 blev gift med Frederik 8. (inv. 1968-626/2).

med mange flotte nuancer af sværtet blyhvidt.

Stikprøveundersøgelsen viste, at der i alt er omkring 200 værker i Det Kongelige Biblioteks samlinger, som har sværtet blyhvidt. Da det er vanskeligt at skelne blyhvidt fra andre hvide pigmenter, er det svært at vurdere hvor mange billeder, der findes med usværtet blyhvidt, men analyser har vist, at der findes eksempler herpå. At der ikke er registreret sværtet blyhvidt i bibliotekets mange værdifulde illuminerede håndskrifter, kan skyldes den beskyttelse mod luftforurening en indbinding giver, $\mathrm{i}$ kombination med opbevaring i magasiner beskyttet mod luftforurening udefra.

Selvom det kun er en lille del af billederne i bibliotekets samlinger, der er 


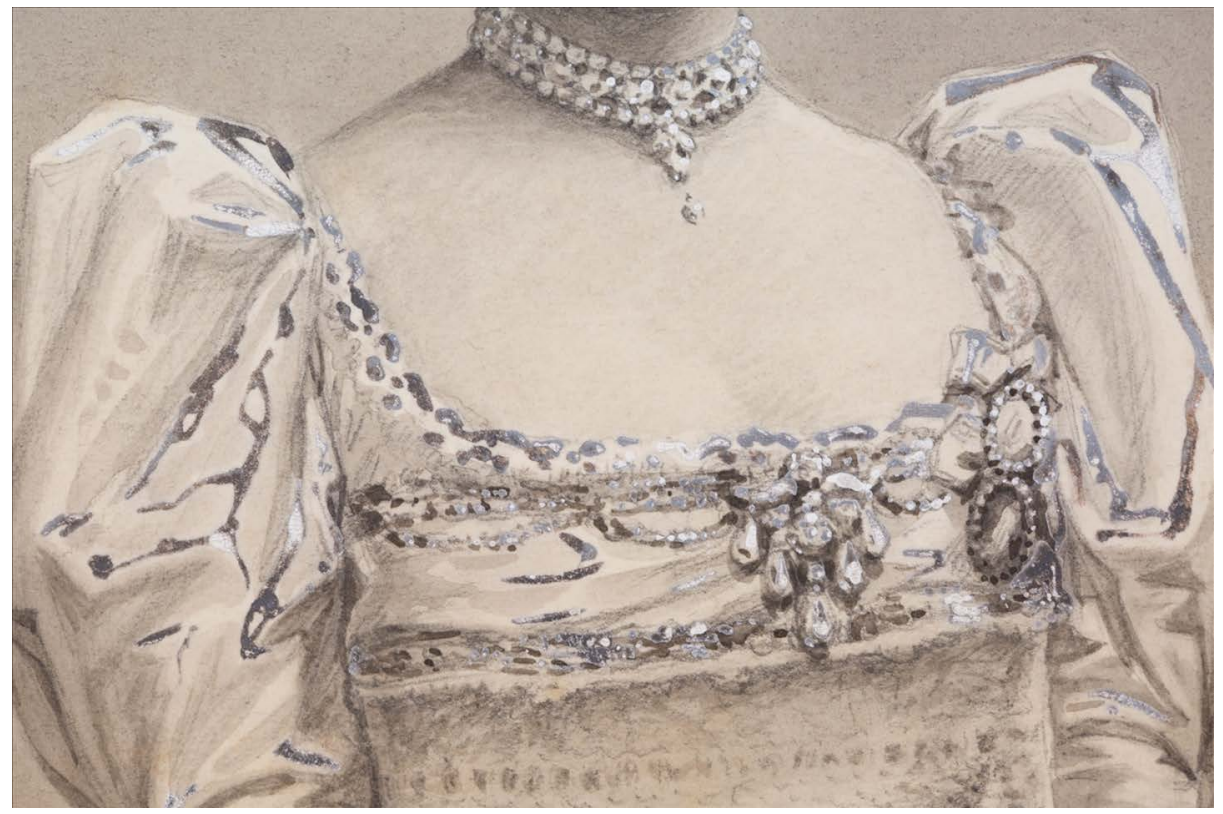

påført blyhvidt og endnu færre af disse, der udviser tegn på sværtning, er skaden forstyrrende for oplevelsen af billederne, så det er vigtigt at identificere forureningskilderne. Kun ved at finde årsagen til skaderne er det muligt at forhindre, at flere billeder med blyhvidt bliver sværtede.

\section{Kilder til sværtning af blyhvidt}

I projektet var mistanken oprindeligt rettet mod en eventuel øget eller ukendt udledning af svovlforbindelser fra bilernes forbrænding efter nye krav om brug af katalysatorer. Systematiske målinger af svovlbrinteniveauet ude og inde påviste et forholdsvist højt niveau både udendørs og indendørs og overraskende, at koncentrationen af denne meget reaktive gas var højere indendørs end udendørs. Koncentrationen indendørs var langt højere end anbefalet til opbevaring af kulturarv, der er følsom overfor luftforurening. ${ }^{3}$ Dette var både tilfældet i magasinerne på SMK og i Diamanten, hvor bibliotekets portrætsamling er placeret, og hvor der også findes en del menneskelig (afgassende) aktivitet på grund af kontorarbejdspladser.

På Centre for Art Technological Studies and Conservation (CATS), ${ }^{4}$ var det muligt at undersøge en anden mistænkt svovlkilde - nemlig emballeringsmaterialerne, altså de omslag og kuverter, der anvendes i bl.a. Portrætsamlingen. Det viste sig desværre, at disse materialer faktisk afgasser svovlforbindelser, som er skadelige for billederne og dermed ikke lever op til tidens standarder for langtidsbevaring af fotografier. ${ }^{5}$ Portrætsamlingens nuværende kuverter og omslag blev skiftet i 1960'erne og erstattede materialer, der af en tidligere medarbejder, blev betegnet 

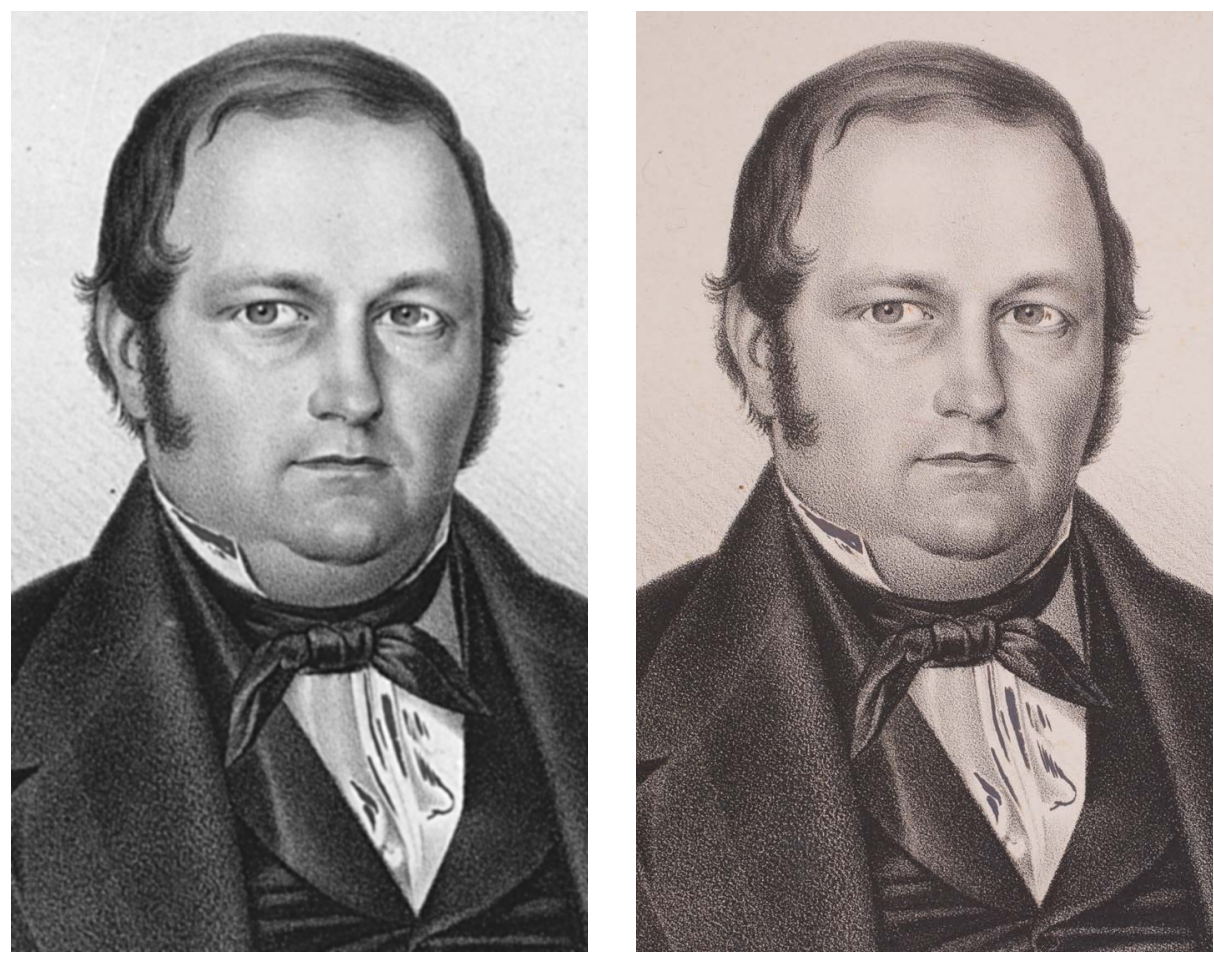

Fig. 7 og 8: Diderik August Holberg (1804-1883). Billede taget aflitografi i Portratsamlingen henholdsvis i 1980 'erne (t.v.) og i 2015 (t.h.).

som værende af langt dårligere kvalitet. Portrætterne har således en længere historie bag sig i uhensigtsmæssige emballeringsmaterialer.

Ved at gå i bibliotekets fotodokumentationsarkiv lykkedes det at finde billedoptagelser fra 1980'erne af tre af de i dag sværtede portrætter. I alle tre tilfælde var det tydeligt, at det blyhvide i billederne allerede var mørkegråt, dengang de blev optaget i 1980 'erne. Fig. 7 og 8 viser et eksempel på et litografi fra Portrætsamlingen reproduceret i 1980'erne (fig. 7) og i 2015 (fig. 8). På begge optagelser kan man se, at retouchen på skjortebrystet er sværtet.
Undersøgelserne tyder således på, at blyhvidtskaderne i Portrætsamlingen på Det Kongelige Bibliotek er af ældre dato. De understøtter endvidere, at skaderne sandsynligvis skyldes afgasning fra ældre svovlholdige emballeringsmaterialer muligvis i kombination med luftforurening udefra og udledning af svovlforbindelser fra menneskelig aktivitet. Især førhen var det almindelig praksis, at mange mennesker arbejdede i magasinområderne.

På SMK tilskrives den pludselige sværtning af de gamle tegninger alene, at de har været opbevaret i et uhensigtsmæssigt magasinklima med en aggressiv kombination af svovlbrinte ude- og indefra, 
høj luftfugtighed og muligvis accelereret af andre udefrakommende luftforureningsforbindelser. Det har ikke kunnet påvises, at emballeringsmaterialerne her er årsagen.

\section{Analyse af nedbrydningsveje}

For at forstå hvilke faktorer der, ud over svovlbrinte, kan påvirke sværtningen af blyhvidt, var en del af projektets tid afsat til analyse af, hvordan farven blyhvidt nedbrydes. De faktorer der undersøges, er blandt andet hvordan pigmentets kemiske sammensætning og det underlag, farven er brugt på, påvirker sværtningen. Til undersøgelse af dette er der fremstillet testmaterialer, der typisk findes i samlingerne (pergament, fotografi og flere papirtyper), som er bemalet med blyhvidt. Disse har enten været eksponeret for svovlbrinte i laboratorium eller opstillet i de magasiner, hvor de sværtede samlinger opbevares på SMK og Det Kongelige Bibliotek. Testmaterialerne

\section{Noter}

1 Projektet blev bevilget af Kulturministeriets Forskningsudvalg i 2015 og er udført i regi af CATS af Anna Vila, David Buti, Morten Ryhl-Svendsen, Niels Borring, Johanne Marie Nielsen, Hanne Karin Sørensen og Birgit Vinther Hansen.

2 <denstoredanske.dk/Kunst_og_kultur/ Fotografi/Fotografiske_processer_og_begreber,_historisk/saltpapir>.

3 American Society of Heating, Refrigeration and Air Conditioning Engineers vil blive undersøgt med analyseudstyr på CATS og er endnu ikke afsluttet.

\section{Indsats for bibliotekets samlinger}

Det faktum at billedsamlingerne i dag opbevares i et miljø med nedbrydende luftforurening fra mennesker og atmosfære samt i emballeringsmaterialer, der skader billederne, er ikke foreneligt med bibliotekets politik om, at kulturarven skal bevares bedst muligt for eftertiden. Derfor prioriterer biblioteket at udskifte alle kuverter og omslag i de berørte samlinger. Ud over sværtning af blyhvidt vil denne indsats også modvirke en lang række af andre skader, som f.eks. udblegning af fotografierne. Desuden vil samlingerne blive flyttet til et nyt magasin, som biblioteket i disse år planlægger at bygge sammen med Nationalmuseet, og som forventes at stå klart i 2021. Luftkvaliteten og klimaet i det nye magasin vil generelt resultere i en betydelig forlængelse af samlingernes forventede levetid.

(ASHRAE). Chapter 21: Museums, libraries and archives. In ASHRAE Handbook: Applications. ASHRAE, Atlanta (2003), s. 21.1-21.16.

4 Om CATS: <kadk.dk/en/centre-art-technological-studies-and-conservation-cats $>$.

5 ISO 18902:2013. Imaging materials Processed imaging materials - albums, framing and storage materials. 
